\title{
민간경호경비조직의 갈등관리방식과 조직성과의 관계 \\ Relations between Conflict Management Style of Private Security Guards in Organizational Effectiveness
}

\author{
박영만, 김은정", 정주섭***, 강호정****** \\ 여주대학*, 경기대학교**, 경원대학교***, 배재대학교 **** \\ Young-Man Park(bir1002@hanmail.net)", Eun-Jung Kim(ejkim1007@hanmail.net)**, \\ Joo-Sub Jung(songdojung@kyungwon.ac.kr) ${ }^{* * *}$, Ho-Jung Kang(hjkang66@pcu.ac.kr) ${ }^{* * *}$
}

\section{요약}

본 연구는 민간경호경비조직의 갈등관리방식과 조직성과의 관계를 규명하는데 목적이 있다. 연구대상은 2010년 서울 소재 민간경비회사에 재직하고 있는 민간경호경비원을 대상으로 판단표집법을 이용하여 286 명을 추출하여 최종분석에 사용된 사례수는 279 명이다. 본 연구에 사용된 설문지의 신뢰도는 Cronbach's a 값이 .642 이상으로 나타났다. 수집된 자료는 SPSSWIN 17.0을 이용하여 요인분석, 신뢰도분석, t검증 및 $\mathrm{F}$ 검증, 다중회귀분석 등의 방법을 활용하였다. 결론은 다음과 같다. 첫째, 민간경호경비원들의 사회인 구학적 특성에 따라 갈등관리방식은 차이가 있다. 둘째, 민간경호경비비원들의 사회인구학적 특성에 따라 조직성과는 차이가 있다. 셋째, 민간경호경비원들의 갈등관리방식은 조직성과에 영향을 미친다. 즉, 민간 경호경비원들의 갈등관리방식은 조직성과에 영향을 미친다. 즉, 통합 - 타협, 회피, 은혜, 지배의 갈등관리 방식을 선호할수록 집단응집력, 조직몰입, 직무만족 또한 높게 나타난다.

1 중심어 : | 민간경호경비 | 조직 | 갈등관리 | 갈등관리방식 | 조직성과 |

\section{Abstract}

The purpose of this study aimed to examine relations between conflict management method and organization of private security companies. 286 guards who worked at security compromies in Seoul in 2010 were selected by using the method of judgment sampling and 279 guards were used for analysis. Reliability of questionnaire used for this study was over .642 in value of Cronbach's a. Collected data was analyzed by using factor analysis, reliability analysis, t-test, F-test, multiple regression analysis and SPSSWIN 17.0. The result is as follows. First, conflict management method for security guards is different depending on socio-demographic features. Second, organizational performance of security guards is different depending on socio-demographic features. Third, conflict management method of security guards has effect on organizational performance. The higher the method of managing conflict through integration, compromise, favor and governance, the higher cohesion, organizational immersion and job satisfaction.

- keyword : | Security Companies | Organization I Conflict Management | Conflict Management Method I Organizational Effectiveness ।

접수번호 : \#100728-001

접수일자 : 2010년 07월 28일
심사완료일 : 2010년 08월 24일

교신저자 : 김은정, e-mail : ejkim1007@hanmail.net 


\section{I. 서 론}

조직은 지속적인 생존과 발전을 추구하는 과정에서 구성원들간의 갈등을 필연적으로 수반하게 된다. 왜냐 하면 조직은 성, 계층, 직위 등과 이해관계 및 욕구가 서 로 상이한 구성원들로 구성되어 있기 때문이다. 갈등은 조직 구성원들간의 대립적, 적대적 관계에서 비롯되며, 특히 조직 내에서의 직위는 갈등 발생과 직간접적인 관 련을 맺고 있다. 갈등은 일반적으로 조직 발전에 부정 적인 영향을 미치는 것으로 인식되어 왔으나, 경우에 따라서는 목표를 효과적으로 달성케 하고 조직의 혁신 과 변화의 수단으로 작용하기도 한다. 조직에서의 갈등 은 어느 사회에서든지 발견되는 보편적 현상이라 할 수 있다[9]. 따라서 리더는 조직 내 모든 갈등을 억제하거 나 제거해서는 안 되며, 갈등의 역기능을 최소화하는 동시에, 순기능을 최대화하여야 한다. 갈등의 순기능을 최대화하여 조직의 효과성을 제고시키기 위해서는 조 직의 갈등을 체계적으로 관리하여야 한다.

민간경호경비 조직은 전문 지식 및 기술을 바탕으로 한 계층적 특성으로 인하여 다른 조직에 비해 더 많은 조직 갈등을 경험한다[14]. 이는 민간경호경비 조직이 소비자에게 범죄의 예방과 국민의 생명을 책임지는 안 전 서비스를 제공한다는 조직의 목표를 성취하기 위한 방법으로, 주로 상사의 의견을 강요하는 위계적, 수직적 조직구조를 갖추고 있는데서 비롯된 현상이라 할 수 있 다. 민간경호경비에 대한 사회적 수요가 급증하면서 나 타나는 업체들간의 경쟁보다는 업체의 영세성, 저임금, 사기저하로 인한 내적 갈등은 조직의 목표 달성과 지속 적 성장 및 발전에 큰 장애물로 작용하고 있다[10].

민간경비원들은 미래지향적 조직관리 관점에서 이해 할 수 있는 이론적 정보를 충분히 제공받지 못하고 있 으며, 특히 조직병리현상에 대한 대안적 성격의 정보는 거의 접하지 못하고 있다. 급변하는 환경에 적응하기 위해서는 보다 능동적이고 효과적인 조직관리가 필요 하다. 이를 위해서는 조직구성원간의 갈등을 효과적으 로 관리할 수 있는 방안을 마련해야 할 것이다. 즉, 단 순히 조직내의 갈등을 해결하는 것이 주된 목적이 아니 라, 갈등을 긍정적 요인으로 도출하여 갈등해소 또는
갈등조장을 통해 조직성과를 증대시킬 수 있다.

그동안 경호경비 연구 영역에서는 조직성과와 관련 하여 조직몰입, 직무만족에 초점을 두고 다수의 연구를 수행하여 왔다[6][8][12]. 그러나 갈등관리와 조직성과 간의 관련성에도 불구하고, 갈등관리와 조직성과에 관 한 연구는 경호경비학은 물론, 전 영역에 걸쳐 매우 미 흡한 실정이라 할 수 있다. 갈등관리와 조직성과의 관 계를 살펴보기 위해서는 다른 사회과학 분야에서 전개 된 선행연구를 고찰해야 한다. 사회과학 분야에서는 Blake와 Mouton[15]이 2차원 모형을 제시한 후, Kilmann과 Thomas[17]의 협조와 주장, Rahim과 Bonoma[20]의 타인과 자신에 대한 관심 등에 대한 이 론적, 경험적 연구들이 진행되어 왔다. 갈등관리 방식의 2 차원 모형은 자신에 대한 관심(주장)과 타인에 대한 관심(협조) 차원으로 구성된다. 이 두 차원을 교차하면 네 가지 차원이 형성되며, 중간수준의 갈등관리 방식이 추가되어 총 다섯 가지 차원이 나타난다. 즉, 경쟁, 양 보, 협동, 회피, 타협 차원이 그것이다[3]. 갈등관리방식 에 관한 초기의 연구들은 갈등관리방식의 이론적 개념 틀 구축과 특성 등을 규명하는데 초점을 두고 있다. 예 컨대, 이창원 - 전주상[13]은 갈등당사자의 상대적 지위 와 개인간 갈등의 관리방식에 관한 연구에서 중안부처 공무원들의 갈등관리 방식은 하급자들과의 관계에서는 대체로 지배방식을 사용하며, 동료들과는 타협방식을 통한 갈등관리방식, 상급자들과의 관계에서는 복종 또 는 회피 방식이 효과적인 갈등관리방식이라고 주장하 였다. 또한 Drake와 Zammuto, 그리고 Parasuraman[17] 은 하급자들은 의견이나 생각이 옳다고 생각하여 타협 이나 통합의 갈등관리방식 보다는 상급자와 갈등으로 일어날 수 있는 적대감이나 불이익이 나타날 수 있기 때문에 갈등을 회피하여 갈등을 해결한다고 보고한 바 있다. 반면에 Rahim[19]은 협력과 통합유형이 상대방 에 대한 높은 수준의 공동 혜택, 더 바람직한 의사결정, 높은 수준의 만족에 영향을 미친다고 주장하였다. 이러 한 선행연구 결과들은 조직의 특성에 따라 갈등관리 방 식과 그 효과성이 상이하게 나타나고 있음을 시사하고 있다. 이와 같이, 조직에 따른 갈등관리방식의 특성이 상이하다면, 갈등관리방식의 최종산물은 과연 무엇인 
가라는 의문을 제기할 수 있을 것이다. 조직이 조직의 특성에 적합한 갈등관리방식을 적용하였을 때 조직이 획득하게 되는 것은 유무형의 성과나 효과성일 것이다. 이와 관련된 선행연구가 소수의 학자 김범성[3], 김선 경, 김영국[5], Hammock \& Richardson[16]에 의해 이 루어졌다. 김범성[3]은 경영자의 개인간 갈등관리 스타 일 및 갈등관리 차원과 경영성과에 관한 연구에서 갈등 관리 스타일이 경영성과에 의미 있는 영향을 미친다고 보고하였다. Hammock와 Richardson[16]은 협력적, 통 합적 갈등해결 방식이 조직의 성과를 유지하는데 상대 적으로 크게 기여한다고 주장하였다. 또한 최근에 이루 어진 김선경, 김영국[5]의 연구에서는 갈등해결 유형 가 운데 협력이 공격이나 회피보다 조직의 성과에 긍정적 인 영향을 미친다고 보고함으로써 본 논제의 타당성을 뒷받침해주고 있다.

그러나 지금까지 경호경비학 연구영역에서는 타 연 구영역에 비해 갈등관리방식과 그 효과성에 관한 연구 자체가 전무한 실정이다. 이 때문에 현재로서는 경호경 비조직의 갈등관리방식이 무엇이며, 다른 조직과 어떠 한 차이를 보이는지, 그리고 그 파급효과인 조직성과에 어떠한 영향을 미치는지를 가늠하기 어렵다. 갈등관리 방식이나 유형에 따라 조직의 성과나 유효성이 상이하 게 나타난다면, 민간경호경비 영역에서도 이에 대한 구 체적인 분석과 논의가 전개되어야 할 것이다.

따라서 이 연구에서는 민간경비원의 갈등관리방식이 조직성과에 미치는 영향을 분석·규명함으로써, 민간 경호경비 분야에서의 경험적 자료를 축적하고 조직성 과에 필요한 기초 자료를 제시하는데 그 필요성을 두고 있다. 이에 본 연구는 민간경호경비원들의 사회인구학 적 특성에 따른 갈등관리방식과 조직성과의 차이점을 분석하고, 나아가 두 변수간의 관계를 규명하는데 연구 의 주된 목적이 있다.

\section{II. 연구방법}

\section{1. 연구대상}

연구는 2010년 서울 소재 민간경비회사에 재직하고
있는 민간경호경비원을 대상으로 선정한 후 판단표집 법(judgment sampling method)을 이용하여 표본을 추 출하였다. 연구대상을 서울로 제한을 둔 이유는 큰 업 체와 민간경비의 사회적 수요가 비교적 많고, 지방업체 의 영세성을 고려했기 때문이다. 이 연구에 사용된 인 원은 총 300 명의 표본을 추출하였으며, 구체적으로 경 찰청에 등록된 경비업체로서 50 인 이상 근무하고 있는 업체 6 개소를 대상으로 1 개소 업체에 50 명씩 총 300 부 를 배부하여 286명의 표본을 회수 하여 최종분석에 279 부를 사용하였다. 연구대상자의 인구통계학적 특성은 [표 1]과 같다.

\section{2. 연구도구}

본 연구에서 사용한 설문지는 사회인구학적 특성 8개 문항, 갈등관리 방식 18 개 문항, 조직성과 15 개 문항으 로 총 41 개 문항으로 구성되었다. 구체적으로 사회인구 학적 특성은 김경식 등[2]의 선행연구를 바탕으로 성, 연령, 학력, 직위, 근무경력, 근무형태, 월수입, 결혼 유 무 등 8개 문항으로 구성하였다. 갈등관리방식 및 조직 성과 설문지는 정세종[14]이 사용한 설문지를 본 연구 에 맞게 수정·보완하여 통합, 은혜, 타협, 지배, 회피 등 5 개의 하위요인 18 개 문항을 사용하였으며, 조직성 과 설문지는 집단응집력, 조직몰입, 직무만족 등 3 개의 하위요인 15 개 문항을 사용하였다. 갈등관리 방식 및 조직성과 척도는 '매우 그렇지 않다(1점)'에서 '매우 그 렇다(5점)'까지 리커트(Likert) 5점 척도로 구성하였다.

\section{표 1. 조사대상의 인구통계학적 특성}

\begin{tabular}{|c|c|c|c|}
\hline & 분 & 사례수(N) & 백분율(\%) \\
\hline \multirow{2}{*}{ 성 } & 남성 & 232 & 83.2 \\
\hline & 여성 & 47 & 16.8 \\
\hline \multirow{3}{*}{ 연 령 } & 20대 & 158 & 56.6 \\
\hline & 30대 & 113 & 40.5 \\
\hline & 40대 이상 & 8 & 2.9 \\
\hline \multirow{3}{*}{ 학 력 } & 고졸 이하 & 25 & 9.6 \\
\hline & 전문대졸 & 126 & 45.2 \\
\hline & 대졸 이상 & 128 & 45.9 \\
\hline \multirow{2}{*}{$\begin{array}{l}\text { 근무 } \\
\text { 경력 }\end{array}$} & 2년 이하 & 70 & 25.1 \\
\hline & 2.1 5년 & 94 & 33.7 \\
\hline
\end{tabular}




\begin{tabular}{|c|c|c|c|}
\hline & 5.1 8년 & 80 & 28.7 \\
\hline & 8.1년 이상 & 35 & 12.5 \\
\hline \multirow{2}{*}{ 직 위 } & 사원급 & 170 & 60.9 \\
\hline & 팀장급 & 109 & 39.1 \\
\hline \multirow{5}{*}{$\begin{array}{l}\text { 근무 } \\
\text { 형태 }\end{array}$} & 시설경비 & 74 & 26.5 \\
\hline & 신변보호 & 120 & 43.0 \\
\hline & 기계경비 & 29 & 10.7 \\
\hline & 호송경비 & 32 & 11.5 \\
\hline & 특수경비 & 24 & 8.6 \\
\hline \multirow{5}{*}{ 월수입 } & 100만원 이하 & 24 & 8.6 \\
\hline & 101 150만원 & 90 & 32.3 \\
\hline & 151 200만원 & 91 & 32.6 \\
\hline & 201 250만원 & 47 & 16.8 \\
\hline & 251만원 이상 & 27 & 9.7 \\
\hline \multirow{2}{*}{$\begin{array}{l}\text { 결혼 } \\
\text { 유무 }\end{array}$} & 미혼 & 181 & 64.9 \\
\hline & 기혼 & 98 & 35.1 \\
\hline & 전 체 & 279 & 100 \\
\hline
\end{tabular}

\section{3. 설문지의 타당도 및 신뢰도}

본 연구에서는 민간경호경비조직의 갈등관리방식과 조직성과의 관계 설문지에 대한 예비검사를 통하여 타 당도 및 신뢰도를 검증하였다. 타당도는 연구자가 측정 하고자 하는 개념이나 속성을 정확히 측정하고 있는가 를 의미하기 때문이다[1]. 설문지의 타당도를 검증하기

위하여 본 연구에서는 체육학 박사학위 소지자 1 인과, 경호안전학 박사 2 인, 경호안전학 박사과정 2 인 등 총 5 인의 관련 전문가 회의를 통해서 설문지에 대한 내용 타당도와 문항의 적합성 여부를 논의하고 지적된 사항 을 수정 - 반영하여 사용하였다. 수집된 자료는 갈등관 리방식, 조직성과를 대상으로 탐색적 요인분석 (exploratory factor analysis)을 이용하여 구성타당도 (construct)를 검증하였으며, 신뢰도 분석(reliability analysis)을 위하여 Cronbach's a 계수를 구하였다.

탐색적 요인분석(exploratory factor analysis) 및 신 뢰도 분석(reliability analysis)을 실시한 결과 [표 2]는 갈등관리방식, [표 3]은 조직성과에 대한 탐색적 요인분 석과 각 요인의 신뢰도 분석결과를 나타내고 있다. 갈 등관리방식은 Cronbach's a 값이 .642 .810로 나타났 으며, 요인5(지배요인)의 경우 요인분석 결과에 의해 두 개의 하위개념으로 분리되었으나 신뢰도가 낮아 삭 제 되었다. 조직성과는 Cronbach's a 값이 .748 .822로 비교적 높은 신뢰도계수를 보이고 있다. 이러한 결과는 갈등관리방식, 조직성과 설문지의 타당도와 신뢰도가 확보되었음을 의미한다.

\section{표 2. 갈등관리 방식에 대한 요인분석 및 신뢰도 분석}

\begin{tabular}{|c|c|c|c|c|c|}
\hline 구분 & $\begin{array}{c}\text { (요인1) } \\
\text { 통합·타협 }\end{array}$ & $\begin{array}{c}\text { (요인2) } \\
\text { 회피 }\end{array}$ & $\begin{array}{c}\text { (요인3) } \\
\text { 은혜 }\end{array}$ & $\begin{array}{c}\text { (요인4) } \\
\text { 지배 }\end{array}$ & $\begin{array}{c}\text { (요인5) } \\
\text { 지배 }\end{array}$ \\
\hline 1. 의사결정을 내리기 위하여 나의 제안과 자신의 제안과 통합 & .859 & .031 & .083 & .083 & .021 \\
\hline 2. 기대를 만족시키는 해결책을 찾기 위하여 나와 의논 & .790 & .071 & .230 & .111 & -.001 \\
\hline 3. 문제해결을 위하여 나와 정확한 정보 교환 & .627 & .288 & .279 & .019 & .062 \\
\hline 4. 타협에 이를 수 있도록 나와 의논 & .585 & .279 & .253 & .129 & .030 \\
\hline 5. 난국을 해결하기 위한 타협방법을 찾으려 노력 & .469 & .388 & .340 & .130 & -.225 \\
\hline 6. 곤란한 감정이 없도록 나와 불일치 될 수 있으면 피함 & .178 & .831 & .105 & .034 & .181 \\
\hline 7. 나와의 불쾌한 의견교환을 피함 & .252 & .749 & .036 & .178 & .079 \\
\hline 8. 나와의 의견충돌을 피함 & .035 & .632 & .243 & .285 & .115 \\
\hline 9. 종종 나의 제안에 찬성 & .203 & .150 & .767 & .028 & .062 \\
\hline 10. 평소에 나의 요청을 받아들임 & .308 & .051 & .733 & .157 & .126 \\
\hline 11. 일반적으로 나의 요구를 만족시키기 위해 노력 & .452 & .235 & .553 & .123 & -.022 \\
\hline 12. 경쟁적인 상황에서 이기기 위하여 자신의 권력을 사용 & .058 & .130 & .164 & .806 & .199 \\
\hline 13. 자신에게 유리한 의사 결정을 위하여 전문지식을 사용 & .214 & .233 & .035 & .786 & .122 \\
\hline 14. 자신에게 유리한 결정을 위하여 권한을 사용 & .028 & .129 & -.082 & .132 & .858 \\
\hline 15. 자신의 제안이 받아들여지도록 영향력을 행사 & -.013 & .142 & .270 & .191 & .731 \\
\hline Rotation Sums of Squared Loadings Total & 2.804 & 2.157 & 1.929 & 1.530 & 1.453 \\
\hline$\%$ of Variance & 18.693 & 14.382 & 12.858 & 10.197 & 9.684 \\
\hline Cumulative \% & 18.693 & 33.075 & 45.933 & 56.13 & 65.815 \\
\hline Cronbach's 훼 & .810 & .734 & .716 & .642 & .594 \\
\hline
\end{tabular}


표 3. 조직성과에 대한 요인분석 및 신뢰도 분석

\begin{tabular}{|c|c|c|c|}
\hline 구분 & $\begin{array}{c}\text { (요인1) } \\
\text { 집단응집력 }\end{array}$ & $\begin{array}{l}\text { (요인2) } \\
\text { 조직몰입 }\end{array}$ & $\begin{array}{c}\text { (요인3) } \\
\text { 직무만족 }\end{array}$ \\
\hline 1. 조직을 비방하는 말을 들으면 울화가 치밈 & .803 & .185 & .068 \\
\hline 2. 조직에 들어오게 된 것을 자랑스럽게 생각함 & .720 & .254 & .218 \\
\hline 3. 직원들은 응집력이 높음 & 680 & .128 & .317 \\
\hline 4. 직원들이 가족처럼 느껴짐 & .658 & .191 & .261 \\
\hline 5. 사무실 직원들이 맘에 듬 & .569 & .498 & .119 \\
\hline 6. 나와 조직이 추구하는 가치가 매우 유사함 & .156 & .805 & .147 \\
\hline 7. 일에 열중하며 시간가는 줄 모름 & .137 & .768 & .215 \\
\hline 8. 친구들에게 내 직업에 대해서 자랑함 & .392 & .576 & .144 \\
\hline 9. 내가 희생하더라도 조직 목표를 달성함 & .370 & .548 & .353 \\
\hline 10. 우리 사무실은 후생복지시설을 잘 갖추었음 & .152 & .241 & .793 \\
\hline 11. 승진할 수 있는 기회가 많음 & .121 & .268 & .746 \\
\hline 12. 내가 담당하고 있는 업무는 개인적 발전에 도움 & .272 & .023 & .720 \\
\hline 13. 나의 능력을 고려 충분한 보수를 받음 & .352 & .332 & .463 \\
\hline Rotation Sums of Squared Loadings Total & 2.951 & 2.509 & 2.365 \\
\hline$\%$ of Variance & 22.704 & 19.300 & 18.189 \\
\hline Cumulative \% & 22.704 & 42.004 & 60.193 \\
\hline Cronbach's 훼 & .822 & .774 & .748 \\
\hline
\end{tabular}

\section{4. 조사절차 및 자료처리}

본 연구에서는 설문지를 판단표집법(judgment sampling method)을 적용하여 민간경비원에게 배부한 다음 자기평가기입법(self-administration method)으로 설문내용에 대하여 응답하도록 하였다. 설문 조사는 연 구자가 해당회사를 직접 방문하여 경영자나 관리자의 협조를 얻은 다음 재직하고 있는 민간경호경비원들에 게 본 연구의 취지를 설명하고 설문내용에 대하여 응답 하도록 하고 완성된 설문지를 회수하여 하였다. 회수 된 설문지의 내용이 부실하거나 신뢰성이 없다고 판단 되는 자료와 극단치(outlier)를 제외하고 최종분석에 사 용하였다.

입력된 자료처리는 SPSSWIN 17.0 Version을 이용 하여 설문지의 타당도 및 신뢰도를 검증하기 위해 요인 분석과 신뢰도분석, 민간경호·경비원의 갈등관리방식 과 조직성과의 차이를 규명하기 위해 $\mathrm{t}$ 검증 및 $\mathrm{F}$ 검증, 민간경호경비원들의 갈등관리방식이 조직성과에 미치 는 영향을 알아보기 위하여 다중회귀분석을 실시하여 결과를 도출 하였다.

\section{III. 연구결과}

\section{1. 민간경호경비조직의 사회인구학적 특성과 갈등}

\section{관리방식 및 조직성과}

\section{1 민간경호경비조직의 사회인구학적 특성과 갈등관 리방식}

[표 4]는 민간경호경비조직의 사회인구학적 특성에 따른 갈등관리방식의 차이에 대한 $\mathrm{t}$ 검증 및 $\mathrm{F}$ 검증을 실 시한 결과이다.

[표 4]에 의하면 성별에 따른 통합·타협, 지배는 남 성 집단에서 높게 나타났으며, 학력에 따른 통합 - 타협, 은혜는 고졸 이하의 집단에서 높게 나타났다. 근무경력 에서는 2 년 이하의 집단에서 통합 - 타협을 높게 인식 하고, 5.1-8년의 근무 집단에서 회피, 은혜, 지배를 높게 인지하고 있는 것으로 나타났다. 월수입에서는 101-150 만원 집단에서 통합-타협을 높게 인식하였으며, 201-250만원 집단에서는 회피, 151-200만원 집단에서 는 은혜, 지배를 높게 인지하고 있는 것으로 나타났다. 결혼유무에 따라서는 미혼 집단들이 지배를 높게 인식 하는 것으로 나타났다. 
표 4. 사회인구학적 특성에 따른 갈등관리방식의 차이에 대한 $\mathrm{t}$ 검증 및 $\mathrm{F}$ 검증의 결과

\begin{tabular}{|c|c|c|c|c|c|}
\hline & 구 분 & 통합·타협 & 회피 & 은혜 & 지배 \\
\hline \multirow{3}{*}{ 성별 } & 남 성(232) & $.663 \pm 3.382$ & $.699 \pm 3.343$ & $.722 \pm 3.444$ & $.805 \pm 3.388$ \\
\hline & 여 성(47) & $.508 \pm 3.672$ & $.662 \pm 3.426$ & $.598 \pm 3.773$ & $.671 \pm 3.319$ \\
\hline & $\mathrm{t}$ 값 & $5.307^{* *}$ & .110 & 3.575 & $4.917^{*}$ \\
\hline \multirow{3}{*}{ 연령 } & 20대(158) & $.650 \pm 3.295$ & $.686 \pm 3.300$ & $.694 \pm 3.334$ & $.796 \pm 3.323$ \\
\hline & $30-40$ 대 $(121)$ & $.603 \pm 3.608$ & $.696 \pm 3.433$ & $.682 \pm 3.714$ & $.763 \pm 3.446$ \\
\hline & $\mathrm{t}$ 값 & 3.023 & .000 & .001 & 1.268 \\
\hline \multirow{4}{*}{ 학력 } & 고졸 이하(25) & $.742 \pm 3.296$ & $.706 \pm 3.453$ & $.757 \pm 3.453$ & $.781 \pm 3.380$ \\
\hline & 전문대졸(126) & $.586 \pm 3.329$ & $.628 \pm 3.278$ & $.638 \pm 3.344$ & $.775 \pm 3.302$ \\
\hline & 대졸 이상(128) & $.669 \pm 3.558$ & $.745 \pm 3.417$ & $.744 \pm 3.499$ & $.791 \pm 3.449$ \\
\hline & $\mathrm{F}$ 값 & $4.682^{* *}$ & 1.549 & $6.612^{* *}$ & 1.130 \\
\hline \multirow{3}{*}{ 직위 } & 사원급(170) & $.642 \pm 3.292$ & $.637 \pm 3.257$ & $.733 \pm 3.412$ & $.761 \pm 3.288$ \\
\hline & 팀장급(109) & $.600 \pm 3.646$ & $.746 \pm 3.514$ & $.661 \pm 3.636$ & $.800 \pm 3.514$ \\
\hline & $\mathrm{t}$ 값 & 1.990 & 1.812 & 2.374 & .417 \\
\hline \multirow{6}{*}{$\begin{array}{l}\text { 근무 } \\
\text { 형태 }\end{array}$} & 시설경비(74) & $.606 \pm 3.443$ & $.588 \pm 3.370$ & $.690 \pm 3.487$ & $.737 \pm 3.365$ \\
\hline & 신변보호(120) & $.683 \pm 3.513$ & $.709 \pm 3.394$ & $.725 \pm 3.550$ & $.802 \pm 3.358$ \\
\hline & 기계경비(29) & $.596 \pm 3.407$ & $.633 \pm 3.344$ & $.748 \pm 3.471$ & $.814 \pm 3.414$ \\
\hline & 호송경비(32) & $.722 \pm 3.312$ & $.841 \pm 3.406$ & $.732 \pm 3.594$ & $.817 \pm 3.516$ \\
\hline & 특수경비(24) & $.488 \pm 3.167$ & $.750 \pm 3.083$ & $.621 \pm 3.194$ & $.780 \pm 3.270$ \\
\hline & $\mathrm{F}$ 값 & 1.784 & 1.076 & 1.415 & .395 \\
\hline \multirow{5}{*}{$\begin{array}{l}\text { 근무 } \\
\text { 경력 }\end{array}$} & 2년이하(70) & $.647 \pm 3.037$ & $.571 \pm 3.048$ & $.673 \pm 3.162$ & $.711 \pm 3.029$ \\
\hline & 2.1-5년(94) & $.604 \pm 3.368$ & $.651 \pm 3.400$ & $.644 \pm 3.411$ & $.714 \pm 3.372$ \\
\hline & 5.1-8년(80) & $.562 \pm 3.687$ & $.734 \pm 3.404$ & $.711 \pm 3.779$ & $.846 \pm 3.575$ \\
\hline & 8.1년이상(35) & $.477 \pm 3.800$ & $.687 \pm 3.752$ & $.640 \pm 3.771$ & $.783 \pm 3.376$ \\
\hline & $\mathrm{F}$ 값 & $20.378^{* * *}$ & $9.520^{* * *}$ & $13.002^{* * *}$ & $8.106^{* * *}$ \\
\hline \multirow{6}{*}{ 월수입 } & 100 만원 이하 & $.382 \pm 2.508$ & $.501 \pm 2.819$ & $.478 \pm 2.722$ & $.741 \pm 2.875$ \\
\hline & 101-150만원 & $.627 \pm 3.211$ & $.668 \pm 3.248$ & $.691 \pm 3.330$ & $.720 \pm 3.256$ \\
\hline & 151-200만원 & $.470 \pm 3.624$ & $.595 \pm 3.381$ & $.660 \pm 3.648$ & $.804 \pm 3.505$ \\
\hline & 201-250만원 & $.518 \pm 3.647$ & $.884 \pm 3.603$ & $.625 \pm 3.617$ & $.765 \pm 3.457$ \\
\hline & 251만원 이상 & $.572 \pm 3.956$ & $.480 \pm 3.691$ & $.568 \pm 4.050$ & $.770 \pm 3.648$ \\
\hline & $\mathrm{F}$ 값 & $32.733^{* * *}$ & $7.991^{* * *}$ & $16.872^{* * *}$ & $4.801^{* * *}$ \\
\hline \multirow{3}{*}{ 결혼유무 } & 미혼(181) & $.653 \pm 3.313$ & $.687 \pm 3.254$ & $.711 \pm 3.354$ & $.802 \pm 3.287$ \\
\hline & 기혼(98) & $.584 \pm 3.650$ & $.664 \pm 3.548$ & $.636 \pm 3.769$ & $.720 \pm 3.541$ \\
\hline & $\mathrm{t}$ 값 & 3.815 & .614 & 1.225 & $5.759^{*}$ \\
\hline
\end{tabular}

${ }^{*} p<.05^{* *} p<.01{ }^{* * *} p<.001$

\section{2 민간경호경비조직의 사회인구학적 특성과 조직성과}

[표 5]는 민간경호경비조직의 사회인구학적 특성에 따른 조직성과의 차이에 대한 $\mathrm{t}$ 검증 및 $\mathrm{F}$ 검증을 실시한 결과이다.

[표 5]에 의하면 성별에 따른 직무만족은 남성 집단 에서 높게 나타났으며, 학력에 집단응집력, 조직몰입은 대졸 이상의 집단에서 높게 나타났다. 근무형태에서는
기계경비 집단에서 집단응집력을 높게 인식하는 것으 로 나타났으며, 근무경력에서는 2년 이하의 집단에서 집단응집력, 조직몰입, 직무만족 모두 인지하고 있는 것 으로 나타났다. 월수입에서는 101-150만원 집단에서 집 단응집력, 조직몰입을 높게 인식하였으며, 201-250만원 집단에서는 직무만족을 높게 인지하고 있는 것으로 나 타났다. 
표 5. 사회인구학적 특성에 따른 조직성과의 차이에 대한 $\mathrm{t}$ 검증 및 $\mathrm{F}$ 검증의 결과

\begin{tabular}{|c|c|c|c|c|}
\hline & 구 분 & 집단응집력 & 조직몰입 & 직무만족 \\
\hline \multirow{3}{*}{ 성별 } & 남 성(232) & $.682 \pm 3.438$ & $.677 \pm 3.400$ & $.632 \pm 3.205$ \\
\hline & 여 성(47) & $.605 \pm 3.728$ & $.641 \pm 3.734$ & $.514 \pm 3.442$ \\
\hline & $\mathrm{t}$ 값 & 2.936 & .645 & $4.564^{*}$ \\
\hline \multirow{3}{*}{ 연령 } & 20대(158) & $.661 \pm 3.352$ & $.643 \pm 3.326$ & $.642 \pm 3.149$ \\
\hline & 30-40대(121) & $.659 \pm 3.665$ & $.696 \pm 3.626$ & $.566 \pm 3.370$ \\
\hline & $\mathrm{t}$ 값 & .243 & .936 & 2.204 \\
\hline \multirow{4}{*}{ 학력 } & 고졸 이하(25) & $.656 \pm 3.488$ & $.618 \pm 3.280$ & $.719 \pm 3.060$ \\
\hline & 전문대졸(126) & $.631 \pm 3.371$ & $.628 \pm 3.306$ & $.583 \pm 3.204$ \\
\hline & 대졸 이상(128) & $.710 \pm 3.601$ & $.703 \pm 3.640$ & $.625 \pm 3.320$ \\
\hline & $\mathrm{t}$ 값 & $3.737^{*}$ & $9.182^{* *}$ & 2.359 \\
\hline \multirow{3}{*}{ 직위 } & 사원급(170) & $.672 \pm 3.393$ & $.688 \pm 3.353$ & $.605 \pm 3.154$ \\
\hline & 팀장급(109) & $.663 \pm 3.635$ & $.643 \pm 3.617$ & $.616 \pm 3.385$ \\
\hline & $\mathrm{t}$ 값 & .193 & 1.190 & .021 \\
\hline \multirow{6}{*}{$\begin{array}{l}\text { 근무 } \\
\text { 형태 }\end{array}$} & 시설경비(74) & $.632 \pm 3.557$ & $.762 \pm 3.497$ & $.566 \pm 3.260$ \\
\hline & 신변보호(120) & $.711 \pm 3.497$ & $.637 \pm 3.427$ & $.618 \pm 3.264$ \\
\hline & 기계경비(29) & $.742 \pm 3.407$ & $.699 \pm 3.551$ & $.570 \pm 3.319$ \\
\hline & 호송경비(32) & $.586 \pm 3.650$ & $.615 \pm 3.617$ & $.786 \pm 3.227$ \\
\hline & 특수경비(24) & $.569 \pm 3.108$ & $.642 \pm 3.146$ & $.591 \pm 3.031$ \\
\hline & $\mathrm{F}$ 값 & $2.707^{*}$ & 1.978 & .866 \\
\hline \multirow{5}{*}{$\begin{array}{l}\text { 근무 } \\
\text { 경력 }\end{array}$} & 2년이하(70) & $.666 \pm 3.163$ & $.668 \pm 3.104$ & $.623 \pm 3.010$ \\
\hline & 2.1-5년(94) & $.635 \pm 3.409$ & $.638 \pm 3.407$ & $.608 \pm 3.231$ \\
\hline & 5.1-8년(80) & $.558 \pm 3.766$ & $.642 \pm 3.725$ & $.598 \pm 3.390$ \\
\hline & 8.1년이상(35) & $.558 \pm 3.766$ & $.583 \pm 3.679$ & $.555 \pm 3.414$ \\
\hline & $\mathrm{F}$ 값 & $13.030^{* * *}$ & $13.359^{* * *}$ & $6.017^{* * *}$ \\
\hline \multirow{6}{*}{ 월수입 } & 100 만원 이하 & $.627 \pm 2.817$ & $.382 \pm 2.729$ & $.489 \pm 2.479$ \\
\hline & 101-150만원 & $.660 \pm 3.302$ & $.721 \pm 3.283$ & $.608 \pm 3.133$ \\
\hline & 151-200만원 & $.632 \pm 3.593$ & $.609 \pm 3.596$ & $.500 \pm 3.414$ \\
\hline & 201-250만원 & $.574 \pm 3.694$ & $.579 \pm 3.654$ & $.644 \pm 3.377$ \\
\hline & 251만원 이상 & $.437 \pm 3.985$ & $.534 \pm 3.861$ & $.487 \pm 3.490$ \\
\hline & $\mathrm{F}$ 값 & $15.548^{* * *}$ & $15.162^{* * *}$ & $16.114^{* * *}$ \\
\hline \multirow{3}{*}{ 결혼유무 } & 미혼(181) & $.660 \pm 3.365$ & $.690 \pm 3.329$ & $.605 \pm 3.201$ \\
\hline & 기혼(98) & $.654 \pm 3.714$ & $.601 \pm 3.691$ & $.639 \pm 3.324$ \\
\hline & $\mathrm{t}$ 값 & .210 & 3.466 & .041 \\
\hline
\end{tabular}

${ }^{*} p \nmid .05{ }^{* *} p \nmid .01{ }^{* * *} p \nmid .001$

\section{2. 민간경호경비조직의 갈등관리방식과 조직성과}

[표 6]은 민간경호경비조직의 갈등관리방식이 조직 성과에 미치는 영향에 대한 회귀분석 결과이다.
표 6. 갈등관리방식이 조직효과성에 미치는 영향에 대한 회 귀분석

\begin{tabular}{llll}
\hline \multicolumn{1}{c}{ 독립변수 } & \multicolumn{1}{c}{ 집단응집력 } & \multicolumn{1}{c}{ 조직몰입 } & \multicolumn{1}{c}{ 직무만족 } \\
\hline \hline 통합·타협 & $.379^{* * *}$ & $.339^{* * *}$ & $.512^{* * *}$ \\
회피 & $.103^{*}$ & -.055 & .031 \\
은혜 & $.287^{* * *}$ & $.339^{* * *}$ & .116 \\
지배 & $.101^{*}$ & $.202^{* * *}$ & .006 \\
\hline $\mathrm{R}^{2}$ & $.506^{* * *}$ & $.476^{* * *}$ & $.376^{* * *}$ \\
\hline
\end{tabular}


[표 6]에 의하면 첫째, 독립변수 갈등관리방식의 하위 요인 통합·타협( $\beta=.379)$, 은혜( $\beta=.287)$, 회피( $\beta$ $=.103)$, 지배 $(\beta=.101)$ 는 집단응집력에 모두 정적영향을 미치는 것으로 나타났다. 이는 조직내 갈등이 발생하였 을 때 통합 - 타협과 은혜 등의 배려를 한다면 집단응집 력이 향상될 수 있음을 보여주고 있다. 회귀분석에 투 입된 독립변수는 영향력 전체변량의 약 $50.6 \%$ 를 설명 해 주고 있다. 둘째, 갈등관리방식의 하위요인 통합 - 타 협( $\beta=.339)$, 은혜( $\beta=.339)$, 지배( $\beta=.202)$ 는 조직몰입 에 정적영향을 미치는 것으로 나타났다. 이는 갈등발생 시 통합 - 타협이나 은혜 등이 조직몰입에 긍정적으로 작용하고 있음을 알 수 있다. 회귀분석에 투입된 독립 변수는 영향력 전체변량의 약 $47.6 \%$ 를 설명해 주고 있 다. 셋째, 갈등관리방식의 하위요인 통합-타협( $\beta$ $=.512)$ 은 직무만족에 정적영향을 미치는 것으로 나타났 다. 이는 갈등발생시 통합 - 타협을 통해 성공적인 업무 와 대안을 마련하여 직무만족에 영향을 미치고 있음을 알 수 있다. 회귀분석에 투입된 독립변수는 영향력 전 체변량의 약 $37.6 \%$ 를 설명해 주고 있다.

\section{IV. 논의 및 결론}

\section{1. 논의}

조직은 정해진 목표를 달성하는 과정에서 다양한 갈 등을 경험한다. 민간경비원 스스로의 복잡한 심리적 작 용에 의한 자신의 내부에서 느끼는 갈등과 근무의 특성 상 근무시간의 불규칙, 임금만족, 승진 기회의 감소, 열 약한 근무환경, 상사- 부하간의 의사소통, 복지후생부 족 등의 요인들이 민간경호경비원들에게 업무상 중요 한 영향을 미치게 되며, 이러한 갈등의 요소들은 조직 성과를 결정짓는다. 갈등관리에 대한 학문적 접근에도 불구하고 지금까지의 선행연구는 조직의 갈등관리에 대한 연구가 거의 전무한 실정이다. 이러한 측면에서 본 연구는 민간경호경비의 갈등관리방식과 조직성과의 관계를 분석하였다.

첫째, 민간경호경비원의 사회인구학적 특성에 따른 갈등관리방식의 차이를 분석한 결과 성별, 학력, 근무경
력, 월수입, 결혼유무에 따라 차이가 있는 것으로 나타 났다. 성별에 따른 통합 - 타협, 지배는 남성 집단에서 높게 나타났다. 이러한 결과는 민간경호경비의 업무특 성상 남성중심의 조직구성으로 이루어져 있어 남성이 여성에 비해 조직내에서 겪는 갈등에 대한 제약이 많음 을 추론할 수 있다. 학력에 따른 통합- 타협, 은혜는 고 졸이하 집단에서 높게 나타났다. 본 연구에서 제시된 바와 같이 약 $90 \%$ 가 넘는 종사자들이 전문대졸 이상의 학력을 가지고 있는데 이는 학력에 따라 달라질 수 있 는 직위에서 서로 다른 갈등의 당사자들이 동등한 권력 을 가지고 있는 상태에서 올수 있는 문제를 고졸학력자 는 대졸학력자에 비하여 기술적 정보력의 부족으로 스 스로 지식정보의 부재를 인식하여 쉽게 상급자, 동료들 과의 타협 및 통합 등을 통한 갈등해결 방식을 선택하 고 있음을 의미한다. 근무경력에 따라서는 2 년 이하의 집단에서 통합 - 타협, 5.1-8년 집단에서 회피, 은혜, 지 배가 높게 나타났다. 2년 이하의 집단은 조직에 대한 이 해와 자신에게 부여된 임무에 대한 책임감 때문에 성공 적인 대안마련의 효과로 통합 - 타협의 갈등관리방식을 높게 인식하며, 5.1-8년 집단은 조직에 대한 자신의 업 무에 대해 중요성과 목표의식에 대해 높게 인식하여 조 직내에서 조화를 촉진시킬 수 있는 위치라고 인식하기 때문에 회피, 은혜, 지배의 갈등관리방식이 높게 작용하 고 있음을 알 수 있다. 월수입에 따라서는 101-150만원 집단에서 통합-타협, 201-250만원 집단에서 회피, 151-200만원 집단에서 은혜, 지배가 높게 나타났다. 임 금은 학력 및 경력 등에 비례하는데 101-150만원 집단 이 통합 - 타협의 갈등관리 방식을 선호하는 것은 학력 및 경력과 같이 자신의 임무에 대한 책임감은 물론, 기 술과 정보의 공유는 업무의 향상과 전문성 숙달에 도움 이 된다는 인식을 가지고 있기 때문이다. 201-250만원 집단에서 회피의 갈등관리방식이 높게 나타난 이유는 자신의 능력이 업무 및 조직에 영향을 미칠 수 있으며 조직으로부터 인정받고 있기 때문에 사소한 문제로 인 해 상대방과 적대함으로써 나타날 수 있는 역효과가 갈 등 해소의 이득보다 더 클 수 있기 때문에 회피하는 경 향을 가지고 있다. 151-200만원 집단에서 은혜, 지배의 갈등관리방식이 높게 나타난 이유는 151-200만원 정도 
의 임금을 받기위해 평균3-4년 정도의 근무경력이 요 구되는데 이 기간이 업무의 전문성 숙달과 조직의 구성 원으로서의 의미성을 가지고 있어 상호 대립하기 보다 는 자신이 양보하거나 포기하며, 갈등을 완화 시키거나 감정을 가라앉히는 방법을 선택하고 있기 때문이다. 그 리고 일상적이거나 현장에서 신속한 결정이 요구될 때 경험 및 기술적인 전문성을 갖지 못한 부하직원을 다룰 때 사용하는 지배방식의 갈등관리방식을 선호한다. 결 혼유무에 따라서는 미혼이 집단에서 지배가 높게 나타 났다.

둘째, 민간경호-경비원의 사회인구학적 특성에 따 른 조직성과의 차이를 분석한 결과 성별, 학력, 근무형 태, 근무경력, 월수입에 따라 차이가 있는 것으로 나타 났다. 성별에 따라서는 남성 집단에서 직무만족이 높게 나타났다. 민간경비조직에서의 여성 근무자는 여러 가 지 환경적 측면에서 남성들과 다른 의미를 가지고 있 다. 근무의 특성상 남성중심의 조직내에서 여성들은 능 력과 성과 등 근무에 대한 비전 및 승진, 창의적인 개발 활동측면에서 남성과는 다소 차이를 보일 수 있으며, 개인과 조직에 대한 자발적 근무에 임하는 것 보다는 비자발적인 근무형태가 되기 때문에 조직갈등에 대해 서 남성과 다소 차이를 가지고 있다. 학력에 따라서는 대졸 이상의 집단에서 집단응집력, 직무만족이 높게 나 타났다. 이는 민간경호경비가 느끼는 만족감이 크며, 전 문적인 지식과 경험을 바탕으로 개인의 역량 발휘를 필 요로 하므로 대졸이상의 학력 소유자들이 조직내에서 전문성을 인정받기위해 상호간의 협력을 통한 집단응 집력 또한 높음을 의미한다. 이와 같은 결과는 학력에 따른 조직성과에 영향을 미치지 않는다는 정세종[14]의 선행연구와는 상반된 결과를 보여주고 있다. 근무형태 에 따라서는 기계경비 집단에서 집단응집력이 높게 나 타났다. 기계경비업무는 자신의 능력과 업무에 대한 전 문적인 지식을 바탕으로 기계경비시스템을 활용하여 신변 및 재산에 대해서 직 - 간접적인 범죄예방 활동으 로 범죄를 줄여주는 업무에 영향을 미침으로써 조직성 과에 큰 영향을 미친다. 근무경력에 따른 집단응집력, 조직몰입, 직무만족 모두 2년 이하의 집단에서 높게 나 타났다. 민간경비업무의 특성상 민강경비원의 연령이
젊은 층에 집중되어 있기 때문에 근무경력 또한 장기 근무자와는 달리 업무에 대한 역할을 자기 스스로 추론 할 수 없으며 자신의 역할이 조직에 작용할 수 있는 직 무에 대한 목표의식을 가지고 있기 때문에 조직성과에 영향을 미치고 있다. 근무경력이 짧고 열악한 근무여건 에도 불구하고 조직성과가 높은 이유는 조직목표에 대 한 사명감 및 몰입도가 비교적 높기 때문이다. 이러한 결과는 이봉행[11], 정세종[14]의 선행연구 결과를 일치 된 맥락에서 지지해 주고 있다. 월수입에 따라서는 101-150만원 집단에서 집단응집력, 조직몰입을 201-250만원집단에서 직무만족이 높게 나타났다. 현 조 직에서의 임금은 자신의 경력과 능력 등 위치를 대변하 는 척도와도 같다. 이는 학력과 경력이 낮을수록 임금 의 수준과 격차에 관심이 많다는 사실을 보여주고 있 다. 월수입의 정도에 따라서 집단응집력과, 조직몰입에 영향을 미치는 요인은 업무 능력의 향상과 전문성 등 조직으로 부터의 인정받기를 원하는 하위 집단에서 높 게 나타나며, 월수입이 높은 집단에서 직무만족과 조직 몰입이 높게 나타나는 이유는 자신의 능력을 조직으로 부터 인정받고 영향력을 발휘하고 직무에 대한 성취욕 을 충족하기 때문이다. 사회인구학적 특성에 따른 갈등 관리 방식 및 조직성과 결과들은 조직내의 갈등관리에 중요한 시사점을 보여주고 있다. Rahim[18]과 Thomas[21]에 따르면 조직내에서 효과적인 최선의 갈 등관리 방식은 정해진 것이 아니라 조직의 환경에 맞는 갈등관리 방식이 최선의 해결이라고 하였다.

셋째, 민간경호경비조직의 갈등관리방식이 조직성과 에 미치는 영향을 분석한 결과 갈등관리방식은 조직성 과 하위요인인 집단응집력에 약 $50.6 \%$ 의 유의한 영향 을 미치는 것으로 나타났다. 이는 민간경비원의 집단응 집력을 높이기 위해서는 집단내의 구성원들간의 갈등 당사자들의 가치를 존중하고 성과나 결과에 무관심하 지 않게 서로 대화하는 분위기를 조성하여 성공적인 업 무처리를 할 수 있는 방안을 마련해야 한다. 지나친 지 시적, 일방적인 지배방식은 조직구성원들을 응집하는 데 적합하지 않다. 조직의 성과를 높이기 위해서는 통 합 - 타협, 은혜의 방식을 채택하여 상호간의 태도에 긍 정적으로 작용할 수 있는 조직을 만들어 구성원들이 공 
유된 가치와 목표를 달성할 수 있도록 노력해야 한다. 이처럼 갈등관리방식이 집단응집력에 영향을 미친다는 본 연구 결과는 정세종[14]의 연구 결과에서 지지해 주 고 있다.

민간경호경비조직의 갈등관리방식이 조직성과 하위 요인인 조직몰입에 약 $47.6 \%$ 의 유의한 영향력을 미치 는 것으로 나타났다. 이러한 결과는 민간경비원들의 계 층구조는 업무적인 성격상 수직적 구조로 이루어져 있 기 때문에 지배적인 갈등관리방식이 효과적인 것으로 생각할 수 있지만, 이러한 구조에서의 갈등은 통합 타협, 은혜의 갈등관리방식의 해결방식을 통해 조직 및 상사, 동료에 대한 신뢰감과 부하직원의 애로 사항 해 결 등의 장기적인 대책을 세워야 할 것이다. 이처럼 갈 등관리 방식이 조직몰입에 영향을 미친다는 본 연구의 결과는 김남현 • 신진교[4], 김일현[7]의 연구와 일치되 는 결과를 보이고 있다.

민간경호경비조직의 갈등관리방식이 조직성과 하위 요인인 직무만족에 약 $37.6 \%$ 의 유의한 영향력을 미치 는 것으로 나타났다. 직무만족은 직무를 통해서 얻을 수 있는 근로조건 지각에서 비롯된다. 임금 및 승진의 기회는 구성원들의 직무에 대한 열정적인 태도로 근무 에 임하도록 직무에 대한 갈등을 해결 한다. 또한, 경영 자와 종사자, 양 당사자들은 서로가 수용할 수 있는 의 사결정을 하기위해 통합 - 타협의 갈등관리방식을 통한 해결방안을 모색하여 업무에 대한 사명감을 높일 수 있 는 민간경비조직내에서 영향력을 행사하여 효과적인 갈등관리가 필요 하다. 무엇보다도 조직내에서 효과적 인 갈등관리방식은 먼저 조직내의 구성원들의 갈등의 수준이 어느 정도인지 파악하여 조직차원에서 미리 예 방을 하거나 관리자는 집단내 개인 및 조직간에 여러 가지 문제들을 수시로 상담과 관심을 통해 조정하는 역 할을 하여 조직 및 갈등 당사자들과의 갈등을 해소시켜 민간경비원들이 조직성과에 긍정적인 영향을 미칠 수 있는 적극적이고 창의적인 노력을 할 수 있는 기회를 제공하여야 한다.

\section{2. 결론}

민간경호경비조직의 갈등관리방식과 조직성과의 관
계를 알아보기 위해서 이상과 같은 연구 방법 및 절차 를 통하여 본 연구에서는 다음과 같은 결론을 도출 하 였다.

첫째, 민간경호경비조직의 사회인구학적 특성에 따 라 갈등관리방식은 차이가 있다. 성별에 따라서는 남성 집단이 통합 - 타협, 지배에서 높았으며, 학력에 따라서 는 고졸 이하의 집단이 통합 - 타협, 은혜에서 높다. 근 무경력에 따라서는 2 년 이하의 집단이 통합-타협, 5.1-8년 집단이 회피, 은혜, 지배에서, 월수입에 따라서 는 101-150만원 집단이 통합 - 타협, 201-250만원 집단 이 회피, 151-200만원 집단이 은혜, 지배에서 높다.

둘째, 민간경호경비조직의 사회인구학적 특성에 따 라 조직성과는 차이가 있다. 성별에 따라서는 남성 집 단이 직무만족, 학력에 따라서는 대졸 이상의 집단이 집단응집력, 직무만족에서 높다. 근무형태에 따라서는 기계경비 집단이 집단응집력에서 높다. 근무경력에 따 른 집단응집력, 조직몰입, 직무만족 모두 2년 이하의 집 단에서 높게 작용하고 있는 것으로 나타났다. 월수입에 따라서는 101-150만원 집단이 집단응집력과 조직몰입 그리고 201-250만원집단이 직무만족에서 높다.

셋째, 민간경호경비조직의 갈등관리방식은 조직성과 에 영향을 미친다. 즉, 통합·타협, 회피, 은혜, 지배의 갈등관리방식을 보일수록 집단응집력, 조직몰입, 직무 만족 또한 높다.

\section{참 고 문 헌}

[1] 김경식, 스포츠과학 연구방법론, 서울: 무지개출 판사, 2005.

[2] 김경식, 김찬선, 이광렬, 김평수, “시큐리티 요원 의 여가관 분석”, 한국콘텐츠학회지, 제9권, 제 1 호, pp.387-399, 2009.

[3] 김범성, "경영자의 개인간 갈등관리 스타일 및 갈 등관리 차원과 경영성과에 관한 연구", 인적자원 개발연구, 제7권, 제2호, pp.35-55. 2005.

[4] 김남현, 신진교, "신세대 조직구성원들의 갈등관 리방식에 관한 탐색적 연구", 인사관리연구, 제 26 
집, 제 1 권, 2002.

[5] 김선경, 김영국, "프랜차이즈 본부의 권력행사가 가맹점의 갈등해결 유형과 성과에 미치는 영향", 호텔경영학연구, 제19권, 제1호, pp.121-135, 2010.

[6] 김상진, "민간경비원의 직무환경에 따른 직무적 합성과 조직유효성의 인과관계", 한국공안행정학 회, 제30권, pp.41-68, 2008.

[7] 김일현, "갈등관리스타일과 조직유효성", 박사학 위논문 경북대학교 대학원, 1996.

[8] 김평수, "시큐리티 종사자의 조직학습이 임파워 먼트 및 조직성과에 미치는 영향", 박사학위논문 경기대학교 대학원, 2005.

[9] 박연호, 조직행동론, 서울: 박영사, 2003.

[10] 안황권, 박영만, "민간경비 산업의 경영환경 (SWOT)분석과 활성화 전략", 한국경호경비학회 지, 제20권, pp.387-399, 2009.

[11] 이봉행, "경찰조직내 커뮤니케이션이 직무만족 에 미치는 영향에 관한 연구", 박사학위논문 동국 대학교 대학원, 2002.

[12] 이원행, "사회적 교환관계와 심리적 계약이 조직 유효성에 미치는 영향", 국내민간경비 경비원을 중심으로, 박사학위논문 숭실대학교 대학원, 2009.

[13] 이창원, 전주상, "갈등당사자의 상대적 지위와 개인간 갈등의 관리방식- 우리나라 중앙부처 공 무원에 대한 실증적 분석", 한국행정학보, 제 37 권, 제2호, pp.1-19, 2003.

[14] 정세종, "경찰 조직내 갈등관리 방식이 조직유효 성에 미치는 영향에 관한 연구", 박사학위논문, 동국대학교 대학원, 2005.

[15] R. R. Blake and J. S. Mouton, "The Managerial Grid". Houston, TX: Gulf, 1964.

[16] G. S. Hammock and D. R. Richardson, "Aggression as one response to conflict. Journal of Applied Social Psychology," Vol.22, pp,298-311, 1992.

[17] R. H. Kilmann and K. W. Thomas, "Developing a forced choice measure of Conflict-handing behavior: The MODE instrument, Education and Psychological Heasurement, Vol.37, No.2, pp.309-325, 1977.

[18] M. A. Rahim, "Managing Conflict in Organization(3rd ed.)," Westport, CT: Quorum Books, 2001.

[19] M. A. Rahim, "Relationship of leader power to compliance and satisfaction with supervision, evidence from a national sample of managers," Journal of Management, Vol.15, pp.545-557, 1989.

[20] M. A. Rahim and T. V. Bonoma, "Managing Organizational Conflict: A Model for Diagnosis and Intervention," Psychological Reports, .Vol.44, pp.1323-1344, 1979.

[21] K. W. Tomas, "Tword Multi-Dimensional Values in Teaching: The Example of Conflict Behaviors," Academy of Management Review. Vol.2, pp.484-490, 1977.

\section{저 자 소 개}

박 영 만(Young-Man Park)

정회원

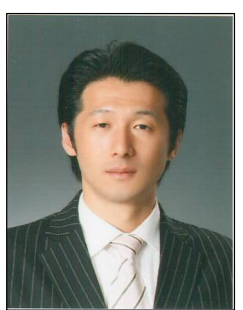

- 2002년 2월 : 한국체육대학교 안 전관리학과(안전학사)

- 2006년 8월 : 한국체육대학교 안 전관리학과(안전학석사)

- 2010년 8월 : 경기대학교경호안 전학과(경호안전학 박사)

- 2008년 9월 현재 : 여주대학 경찰경호과 외래교수 <관심분야> : 시큐리티 경영, 민간경비, 경호무도 


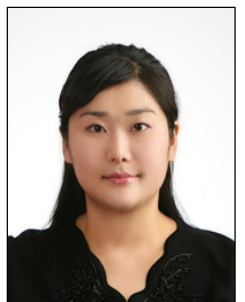

- 1999년 2월 : 한국체육대학교 경기지도과(체육학사)

- 2001년 2월 : 용인대학교 일반 대학원(체육학석사)

- 2009년 3월 : 경기대학교 경호안 전학과(박사과정)

- 2009년 3월 현재 : 경기대학교 경호안전학과, 서울 여자대학교, 여주대학강사

<관심분야> : 경호정책, 경호무도, 경호안전관리

\section{정 주 섭(Joo-Sub Jung)}

정회원

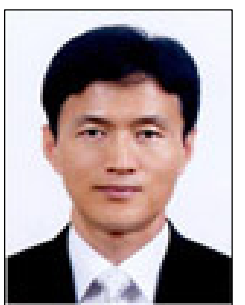

- 1985년 2월 : 홍익대학교 건축학 과(건축학사)

- 2001년 2월 : 인하대학교 교육대 학원(교육학석사)

- 2005년 2월 : 경기대학교 대학원 경호안전학과(경호안전학박사)

- 현재 : 경원대학교 태권도학과 교수

<관심분야> : 경호학, 테러학, 경호무도

강 호 정(Ho-Jung Kang)

종신회원

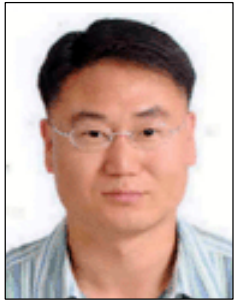

- 1991년 2월 : 충남대학교 경영학 과(경영학사)

- 1993년 2월 : 서울대학교 대학원 경영학과(경영학석사)

- 2000년 2월 : 서울대학교 대학원 경영학과(경영학박사)

- 현재 : 배재대학교 경영학과 교수

<관심분야> : 기업재무, 투자론, 스포츠경영 